1996

\title{
The Contagion of Women Candidates in Single- Member District and Proportional Representation Electoral Systems: Canada and Norway
}

Richard E. Matland

Donley T. Studlar

Follow this and additional works at: https://researchrepository.wvu.edu/faculty_publications

\section{Digital Commons Citation}

Matland, Richard E. and Studlar, Donley T., "The Contagion of Women Candidates in Single-Member District and Proportional Representation Electoral Systems: Canada and Norway" (1996). Faculty Scholarship. 365.

https://researchrepository.wvu.edu/faculty_publications/365 


\section{CAMBRIDGE \\ UNIVERSITY PRESS}

\section{Southern Political Science Association}

The Contagion of Women Candidates in Single-Member District and Proportional Representation Electoral Systems: Canada and Norway Author(s): Richard E. Matland and Donley T. Studlar

Source: The Journal of Politics, Vol. 58, No. 3 (Aug., 1996), pp. 707-733

Published by: Cambridge University Press on behalf of the Southern Political Science Association

Stable URL: http://www.jstor.org/stable/2960439

Accessed: 24/09/2011 20:46

Your use of the JSTOR archive indicates your acceptance of the Terms \& Conditions of Use, available at http://www.jstor.org/page/info/about/policies/terms.jsp

JSTOR is a not-for-profit service that helps scholars, researchers, and students discover, use, and build upon a wide range of content in a trusted digital archive. We use information technology and tools to increase productivity and facilitate new forms of scholarship. For more information about JSTOR, please contact support@jstor.org. 


\title{
The Contagion of Women Candidates in Single-Member District and Proportional Representation Electoral Systems: Canada and Normay
}

\author{
Richard E. Matland \\ University of Houston \\ Donley T. Studlar \\ West Virginia University
}

There is a distinct gap in women's representation in national legislatures between countries with single-member district electoral systems and those with proportional representation electoral systems. While this gap has been well documented, there have been only limited attempts at explaining its existence. After reviewing the literature on the representation gap, we turn to the party change literature and propose a modified contagion theory as one possible explanation for the gap. Contagion theory suggests that traditional parties will feel pressured to nominate more women if one of their political rivals, usually a smaller party farther to the left, starts to promote representation of women. We distinguish between macrocontagion and microcontagion and argue that especially microcontagion is more likely to occur in party list proportional representation systems than in single-member district systems. This should be true because contagion pressures are more likely to develop, and the costs of adapting to these pressures are less, in party list proportional representation systems. We formally test for microcontagion at the electoral district level in Canada and Norway, both leaders among their type of electoral systems in female representation. The data confirm our hypothesis by showing no indication of microcontagion in Canada, but evidence of such an effect in Norway.

\section{INTRODUCTION}

It is well established that multimember district electoral systems, especially party list proportional representation systems, tend to have substantially higher percentages of women legislators than single-member district systems (Duverger 1955; Lakeman 1970; Castles 1981; Rule 1981; 1987; Norris 1985; 1987). In 1993,

Earlier versions of this article were presented at the European Consortium for Political Research Workshops, Madrid, April 1994, and the Midwest Political Science Association, Chicago, April 1993. Richard E. Matland would like to thank NATO for its support of this research through its grant program in Democratic Institutions. David Wright of the University of Houston provided valuable research assistance. In addition, the contributions of Charles Franklin, Mark Franklin, three anonymous reviewers, and the Gen-U-Wine Oyster Bar in Bastrop, Texas, are gladly acknowledged.

The Journal of Politics, Vol. 58, No. 3, August 1996, Pp. 707-33

(C) 1996 by the University of Texas Press, P.O. Box 7819, Austin, TX 78713-7819 
Western democracies with party list proportional representation systems had 20\% female legislators, while single-member district countries had 9\% (Inter Parliamentary Union 1993). In Germany, where half of the members of the Bundestag are elected from each type of system, the multimember system contributes twice as many women as does the single-member component (Lancaster and Davis 1992). The number of women has increased within most systems in the wake of "secondgeneration" feminism (Randall 1987). These increases have been much more rapid, however, in party list proportional representation systems. The existence of a gap between the two types of electoral systems is well documented. Explaining why the gap occurs, however, has proven to be more difficult.

This article suggests an answer to part of the puzzle by developing a theoretically based explanation of why variations in women's representation occur across electoral systems. Starting from the literature on political party change, we investigate the phenomenon of contagion in nominating and electing female candidates to the national legislature in two polities, Canada and Norway. Contagion is a process by which one party in a multiparty system, stimulates other parties to adopt their policies or strategies. We will look at contagion in terms of a party, usually a small one, that induces other parties, usually larger ones, to nominate more women candidates. While contagion pressures should exist in both countries, we expect the electoral system to play an important role as an intervening variable. Contagion is more likely to operate effectively in a proportional representation, party list system than in a single-member district system. This helps account for why proportional representation systems have both higher proportions of women legislators and have had faster increases in the proportion of women members.

\section{LITERATURE REVIEW}

Scholars have noted and commented upon variations in women's elected representation from many different perspectives. Women's representation levels are influenced by a number of factors. Some authors have emphasized the role of interest groups and social movements, particularly the strength of the women's movement (Katzenstein and Mueller 1987; Bystydzienski 1988; Gelb 1989; see, however, Bashevkin 1994). Another common explanation for differences in representation is political culture. The Nordic countries are all among the highest in proportion of women parliamentarians, ranging up to $40 \%$. This has led some observers to claim that the political culture in these countries is more favorable toward women (Norris 1987; Bystydzienski 1988; see, however, Matland 1994).

While several sources of variation have been identified, there is general agreement that electoral institutions are an important factor affecting the levels of women's representation. Multivariate cross-national investigations have consistently shown that the electoral system, especially the difference between party list proportional representation and single-member district, simple plurality systems, is the most important variable affecting women's share of legislative seats (Rule 1981; 1987; Norris 1985; 1987). 
While researchers have identified the electoral system as a major influence on the number of women who become legislators, why this should be the case has never really been settled. Several researchers suggest that structural features of the electoral system help explain the differences. In proportional representation systems, for example, parties balance their tickets by including viable female candidates on the party list in order to appeal to a broad portion of the electorate. Ticket balancing is impossible, however, in single-member districts where only one person carries the party banner. Others have argued that the larger district magnitudes (number of seats per district) in multimember systems provide for lower thresholds for women to cross when seeking nominations (Engstrom 1987; Rule 1987; Matland 1993). Another structural factor is the relatively centralized nomination procedures that usually apply in party list systems (Castles 1981; Gallagher and Marsh 1988). Centralized control over nominations means that party elites can increase the number of viable women candidates in response to pressure for greater representation. Most single-member district systems tend to have decentralized nomination structures; because of this central party organs wanting to increase women's representation have considerable difficulties in getting their wishes carried out at the local level (Norris 1993). Finally, the decreased emphasis on individual incumbency and greater turnover characteristic of proportional representation (PR) systems result in greater opportunities for women in such systems (Matland and Studlar 1995).

Several authors have noted the absolute difference in female representation between single-member district and multimember district proportional representation systems. As table 1 and figure 1 show, however, there are also significant differences in developments over time. ${ }^{1}$ As is immediately obvious from figure 1 , representation levels have grown much more quickly in PR systems than in singlemember district systems. While a moderate gap existed between the two systems from post-World War II until 1970, after 1970 there is a substantial and significant increase in the gap. Female representation jumped in the PR countries from $6.0 \%$ in 1970 to $20.2 \%$ in 1993 . A much smaller increase in women's representation occurred in the single-member district countries as representation crept up from $2.2 \%$ to $9.5 \%$. The increases among the PR system countries were also broad. Women increased their representation by more than $10 \%$ in 11 of the 16 PR system countries that had open elections in both 1970 and 1993. Women increased their representation by more than $10 \%$ in only two of the seven single-member district countries. Students of women's representation in single-member district systems have projected the increase of women in the legislature will continue at a very slow pace until the middle of the twenty-first century (Andersen and Thorson 1984; Darcy and Choike 1986; Norris, Vallance, and Lovenduski 1992).

Thus, despite similar social pressures since the mid-1960s to increase women's legislative representation in all Western democracies, the success of these demands

\footnotetext{
${ }^{1}$ We use the 23 countries Rule uses in her 1987 cross-national study of women's representation. We also use her definitions of single member and PR systems. Updated data are supplied by the Inter Parliamentary Union (1993).
} 
TABLE 1

Percent of MPs Who Were Women

ACROSS 23 National Legislatures, 1945-1993

\begin{tabular}{lrrrrrrr}
\hline $\begin{array}{l}\text { System/ } \\
\text { Year }\end{array}$ & 1945 & 1950 & 1960 & 1970 & 1980 & 1990 & 1993 \\
\hline SMD & 3.05 & 2.13 & 2.51 & 2.23 & 3.37 & 8.16 & 9.47 \\
PR & 3.16 & 5.05 & 5.86 & 6.03 & 11.79 & 18.43 & 20.16 \\
\hline
\end{tabular}

Definitions:

Single-member district systems (SMD): Australia, Canada, France (1960 and beyond), Japan' ${ }^{1}$ New Zealand, United Kingdom, and United States.

Proportional Representation Systems (PR): Austria, Belgium, Denmark, Finland, France (1945 and 1950), Greece*, Iceland, Ireland, Israel**, Italy, Netherlands, Norway, Portugal*, Spain*, Sweden, Switzerland, and West Germany**.

${ }^{1}$ Technically, Japan does not have a single-member district system. The Japanese electoral system at this time was Single Nontransferable Vote system and formally this is a PR system. The way the system functions in practice, however, with each voter having only one vote, is generally considered by electoral system experts to be closer to a single member district system than a traditional proportional representation system (Rule 1987, personal conversation, Richard Katz).

* Greece, Portugal, and Spain became democratic in the 1970s and are therefore only included in the 1980,1990 , and 1993 figures.

** Israel did not exist and West Germany did not hold elections in 1945. They are therefore not included in 1945. They are included for all years following 1945.

has varied considerably. As figure 1 makes clear, these demands have been more successfully translated into representation in parliaments in proportional representation systems than in single-member district systems. While there have been similar systemic demands across countries, because different institutions process these demands, they lead to different results (Chamberlin 1990). Our goal is to provide an explanation for why PR systems have been more open to demands for representation by women, especially during the past 20 years. The model we present suggests both the dynamics of party competition and the nature of electoral institutions are important factors in increases in female representation.

\section{Theoretical Model}

Contagion is not a new concept in the parties literature. Duverger (1954) first suggested that a "contagion from the left" would occur among political parties, with Conservative and Liberal cadre parties being forced to emulate the Socialist parties by developing into mass membership parties or else face the danger of electoral defeat. Epstein (1967) responded with the idea of "contagion from the right," whereby leftist parties would be forced to adapt to the use of modern campaigning techniques such as public opinion surveys and mass media advertising, first developed by parties on the right. Kirchheimer (1966) saw a movement among parties away from their distinctive forms and ideologies and toward much broader and 





shallower entities that he described as catch-all parties. The need to replicate successful electoral strategies developed by one's competitors, in order to remain competitive, would drive these processes of imitation.

The degree to which these various contagions have spread across individual parties is a question of some controversy. While there is evidence that parties have adopted similar policies in some areas (Krouwel 1994), parties have also retained distinctive elements. More recent theorizing on individual party change has tended to emphasize the conservative nature of organizations and the general opposition within an organization to change (Panebianco 1988; Harmel and Janda 1994). It is not that parties do not change, only that change is often a difficult process requiring considerable effort. To move in a specific direction in reaction to some external event requires agreement on the interpretation of the external event or shock, a willingness by the dominant coalition within the party to support a change, and the resources to implement the agreed-upon change. Often one or more of these elements are missing.

While our primary emphasis is on establishing an explanation for the differences across electoral systems in women's representation, we also believe light can be shed on the general question of party adaptation by looking at one specific party decision across systems. We will look at the decision to increase the number of women nominated for the central legislature and whether we can discern a contagion effect on this element of party activity.

Our version of contagion theory suggests that as smaller but competitive parties, usually on the political fringe, start to promote women actively, larger parties will move to emulate them. This should happen for at least two reasons. First, by nominating women, smaller parties may demonstrate that there is no electoral penalty associated with women candidates. Although it was a common excuse for not nominating women in earlier years (Ranney 1965; Bochel and Denver 1983), research has repeatedly shown this fear of public antipathy toward women candidates is almost completely groundless in Western democracies in the 1970s and 1980s (Darcy and Schramm 1977; Rasmussen 1983; Hunter and Denton 1984; Kelley and McAllister 1984; Welch and Studlar 1986). Second, larger parties will feel increased pressure to respond by more actively promoting women themselves. This will be especially true for parties which are ideologically close to the parties initiating promotion of women candidates. These parties would fear losing voters to the innovating party. Over time, as each party reacts to a felt threat from close political rivals on the issue of equity in representation, the perceived need to nominate women will flow across the political system to virtually all parties. The expectation is that all the mainstream parties will eventually start nominating appreciable numbers of women candidates to demonstrate their commitment to equal rights. Since this process is driven by party competition we expect contagion to exist in both single-member and PR systems. We expect, however, that the process will be more effective in bringing women into office and spread more quickly in multimember proportional representation systems. 
There are three reasons why this process should be more effective in PR systems. First, single-member district systems tend to be two party systems; they often lack the stimulus of a minor party innovating on the issue of women's nominations. Unless pushed on the issue of representation, the dominant coalition within a party may see little need to disrupt existing routines to promote more women as candidates. When no viable third party exists, women activists and their supporters have to argue for better representation largely on equity grounds. If there is an active third party, however, the faction within the party promoting women candidates can bolster the equity argument with a strategic argument that the party is in danger of losing votes unless it responds. As a general point, the greater number of parties in proportional representation systems provides an increased probability that one party will decide actively to promote women candidates and set the contagion process in motion. A party's need to find issues on which it can take strong stands in order to attract supporters also increases this likelihood. ${ }^{2}$

The second reason contagion should be more common in PR systems is that the political costs of responding to this challenge are smaller. It is easier for a major political party to respond in a PR system than in a single-member district system. This is especially true where district magnitude, the number of seats per district, is large. Under these conditions, ticket balancing is substantially easier because a major party can expect to win several seats in each district. It is therefore possible for the party to nominate women without having to depose more powerful intraparty interests. In the single-member district, however, responding to the thirdparty challenge may require deposing an incumbent or challenging a central party interest. Under these conditions, even if the party wanted to respond, it might decide that it is better to ignore the external challenge from the third party than to risk creating internal strife and antagonizing powerful intraparty interests. ${ }^{3}$

The third reason for contagion's expected greater effectiveness in PR systems is that the threat of losing votes is more serious and therefore more worthy of a counterreaction in a PR system than in single-member district systems. The differences in the costs of losing votes in the two systems create this effect. In a

\footnotetext{
${ }^{2}$ Recent work on party-voter interactions, done under the rubric of directional theory, has found that voters tend to evaluate most positively those parties that take the strongest stands on an issue important to voters and not necessarily the party which may be closest to their own position in issue space (MacDonald, Listhaug, and Rabinowitz 1991; Rabinowitz, MacDonald, and Listhaug 1991). The implication of this research for party strategists is clear, a party should take aggressive stands on the issues of importance to its constituents.

${ }^{3}$ The organizational theory literature has been interested in the question of inertia and ability to respond to environmental changes for quite some time. March and Simon (1958) were among the first to point out that internal constraints on actions are often sufficient to lead to inaction even when external threats are clearly recognized. Hannan and Freeman $(1977,1984,1989)$ have argued that such inertia is extremely common and that organizations are often unable to adapt when such adaptation presents significant short-term costs to central organization actors, even when there is a clear long-term payoff for the organization.
} 
single-member district system, a party's overwhelming concern is finishing first. The margin of victory is a smaller concern. Therefore actions by a minor party that threaten to siphon off some votes, perhaps even a substantial number of votes, but do not threaten the dominant party's position as number one in the district, can be safely ignored. In effect, in safe districts we would not expect to see the dominant party pay great attention to minor party actions. Compare this with the situation in proportional representation systems with large district magnitudes. Even minor shifts in the major party's vote total can affect their total number of seats. Therefore, even when a party is dominant in the district, it must take very seriously the danger of losing a few percentage points off its vote. The costs of failing to react will not merely be the symbolic cost of a smaller victory margin, but the very real cost of fewer seats in parliament.

Contagion theory suggests that the contours of the party system, as well as the electoral system, are of critical importance for the advancement of women's legislative numbers. Quite often the smaller parties that set the process in motion elect very few representatives and do not noticeably contribute to the increased number of women in the parliament. When the larger parties react to their example by nominating women to viable seats, however, substantial increases in representation occur. Since we predict major party reaction is more likely to occur in proportional representation systems, there should be a significant difference across the two systems in female representation.

One final theoretical distinction concerning contagion needs to be made. We distinguish between macrocontagion and microcontagion. Macrocontagion occurs at the national or central level. Microcontagion occurs at the local or electoral district level. Macrocontagion is a process where a party responds to general political pressure from competing parties on the issue of representation by increasing its promotion of women across constituencies, but not necessarily in the same districts as where other parties nominate women. It is sufficient for the party to be able to show that it is willing to nominate women, with at least some of them in competitive districts. Macrocontagion should have the general effect of raising levels of women's representation across all districts. This is likely to influence virtually all parties, although with different intensities. Microcontagion is district specific and occurs when a party's constituency candidate selection meeting decides to increase the number of women in electable positions, as a response to the nomination of women in prominent positions by its competitors mithin the district. Microcontagion is a response at the local district level to pressure generated at the local level.

Micro- and macrocontagion are independent processes, but they are generally complementary. For example, if microcontagion occurs in individual districts, it may increase the pressure at the national level to adopt more general rules of equal representation. The distinctions between the two processes are important for several reasons. One is that they predict different patterns of diffusion of women candidates. While macrocontagion predicts a general rise in the number of women candidates throughout all constituencies in the country, microcontagion predicts that 
women candidates will be clustered disproportionately in those districts where the innovating parties promoting women have nominated women at a prominent level. A second important reason for distinguishing between these processes is that we believe macrocontagion is likely to occur in all systems, while microcontagion is more likely to appear in PR systems. Finally, distinguishing between the two types helps sharpen our perspectives on how to test empirically for contagion of both varieties.

We know of no explicit attempts at testing for macrocontagion. In several single country case studies, however, there is substantial anecdotal evidence that suggests that minor parties are often the innovators in nominating large numbers of women for parliamentary seats. ${ }^{4}$ In countries as diverse as Canada, Norway, Germany, the United Kingdom, Italy, New Zealand, and France, smaller parties, especially those on the left, have led the way (Aitken 1980; Vallance 1984; Brodie 1985; Bystydzienski 1988; Beckwith 1990; Kolinsky 1991; Bashevkin 1993; Norris and Lovenduski 1993). In the analysis below, we present a description of the development of women's candidacies in Norway and Canada in an attempt to gauge macrocontagion's relevance in these countries.

The only formal test of the microcontagion hypothesis examined local elections in England, a single-member district system with an emerging third party challenger having policies favorable toward women (Studlar and Welch 1992). In the mid-1980s the Alliance, an electoral pact between the Liberal and Social Democratic parties, challenged the two-party dominance of the Conservatives and Labour. The Alliance had strong women's advocacy positions, including a requirement that women be placed on the short list for parliamentary candidacies. The results for the 1986 English Metropolitan district elections show weak support for the contagion hypothesis. Controlling for other variables, Labour was somewhat more willing to run women candidates in three-party rather than two-party contests. After the discussion of macrocontagion we will turn to microcontagion and present formal tests of microcontagion in both Canada and Norway.

\section{Macrocontagion: The Norwegian and Canadian Cases}

We use parliamentary elections in Norway and Canada for a more systematic test of the contagion hypothesis. Both are leaders in women's legislative representation among countries with their particular electoral arrangements. Norway, with $39 \%$ women legislators after the 1993 election, is second among party list proportional representation countries (after Sweden). Canada, with 18\% women legislators after the 1993 election, is second among single-member district countries to New Zealand, with $21 \% .{ }^{5}$ Both have multiparty systems. In Norway eight parties have seats in the Storting after the 1993 election-Red Electoral Alliance, Socialist

\footnotetext{
${ }^{4}$ Contagion from minor to major parties has also been found to affect an arena far from women's representation, namely government spending. See Petry (1988) and Hofferbert and Budge (1992).

${ }^{5}$ In 1994, New Zealand voted by referendum to alter its electoral system to a mixed (German-type) system. The sitting Parliament, however, was elected in November 1993 using a single-member district system.
} 
Left, Labour, Liberals, Center Party, Christian Democrats, Conservatives, and the Progress Party. Before the 1993 elections, the previous quarter century in Canada had seen three-party competition for national office between the Progressive Conservatives, Liberals, and New Democrats. In the 1993 elections two insurgent parties, the Bloc Quebecois and the Reform party, made significant inroads into the House of Commons, while the Conservatives and NDP suffered substantial setbacks. Five parties are therefore represented in the present House of Commons.

\section{Representation of Women in Norway}

The rise of women to legislative power in Norway has been well documented (Means 1972, 1973; Haavio-Mannila et al. 1985; Bystydzienski 1988, 1994; Matland 1993, 1995). From a low point in the 1960s, women have organized themselves and political parties across the spectrum have responded sufficiently to make Norway a world leader in female elite representation, not only in the legislature but also in the Cabinet, where $47 \%$ of the ministers are women. The female prime minister of Norway, Gro Harlem Brundtland, has been the leader of the largest party, Labour, for 15 years. Three of the six major party leaders during the last parliamentary election (for the Labour, Conservative, and Center parties) were women. While Norway's position as a world leader is well established, there is still a debate about the relative importance of various factors in the rise of women-electoral system, social movement organizations, party nomination procedures, district magnitude, and political culture.

The first movements to promote improved representation of women in Norway occurred in the 1960s. There were active campaigns before the 1967 and 1971 local elections and before the 1969 national elections to increase women's representation on party lists (Bystydzienski 1988). These initial movements were cross-party promotional campaigns where prominent party leaders from several parties, in unison, urged all parties to increase their representation of women. No party clearly stepped forward as most concerned with representation, although most parties exhibited some willingness to incorporate more women. Interestingly, in discussing party nominating procedures, Valen (1966) describes a process that fits the contagion model quite well. He suggests that in local elections many party lists had previously only included men among those who had a viable chance of getting elected. Once one party declared an intention to nominate a woman in a viable position, however, all parties would rush to nominate a woman in a viable position. The willingness to support women, however, was often limited to token representation. There was an interest in having a single woman on the list in an electable position, but true equality was not seriously considered (Means 1973; Christiansen 1979; Matland 1993). Nevertheless, the proportion of women in the Norwegian Storting increased from $6.7 \%$ to $15.5 \%$ from 1957 to 1973 .

The 1970s brought improved access as women's representation in the Storting jumped $10 \%$, from $15.5 \%$ in 1973 to $25.8 \%$ in 1981 . The mid to late $1970 \mathrm{~s}$ also saw significant differences in willingness to incorporate demands for greater 
representation. Cross-party movements faded; the emphasis was on internal party pressures. Energized by its active opposition to the EEC referendum in 1972, the Socialist Left scored its best election ever in the 1973 national elections, increasing its representation from zero to 16 members (of 155 total members). The Socialist Left adopted numerous feminist planks in their party program throughout the 1970s and became identified increasingly with this position. The Socialist Left made a crucial decision in 1977 when they established quotas. Starting with the 1977 elections, $50 \%$ of all Socialist Left candidates were to be women. The Liberal party, Norway's oldest political party, had split over the issue of joining the Common Market and was virtually decimated in the 1973 elections. In the years leading up to the next parliamentary election, they developed a political profile that emphasized green politics, but also included important elements of women's rights. A woman, Eva Kolstad, was elected party leader in 1974. In 1977, the Liberals passed a resolution that at least $40 \%$ of its parliamentary candidates would be women (Grepstad and Nerbøvik 1984). The issue of equal representation was also actively considered in the other parties and pressure was applied in these parties. While this led to some increase in representation, no formal policies were approved to bolster women's positions.

The 1980s saw another jump of $10 \%$ in overall women's legislative representation, from $25.8 \%$ in 1981 to $35.8 \%$ in 1989 . The most crucial action in the $1980 \mathrm{~s}$ was the Labour party's decision in 1983 to establish quotas. Once established, and honored, quotas in a proportional representation system virtually guarantee that representation will improve. The quotas had an immediate and clear impact on the Labour delegation as it went from $33 \%$ female in 1981 to $51 \%$ female in 1989 . This increased pressure on the other parties to increase their female representation. All parties, except the Progress party, did so in the 1980s. At the end of the decade the Center party became the fourth party to establish formal gender quotas for candidates. After the 1993 elections the proportion of the Norwegian Members of Parliament who were women reached $39 \%$.

The development of female representation in Norway can be partially described as an example of macrocontagion. The national Labour party's recognition of the pressure from the Socialist Left and the Liberals to nominate women, and the initial urging from the central offices to their local nominating caucuses to consider more women, is an example of macrocontagion. The decision by the national convention in 1983 to adopt quotas is also an example of macrocontagion. While macrocontagion processes are important, we believe that microcontagion processes also play an important role in the general advance of women in Norway. We will test for microcontagion by seeing whether Labour tended to provide women with better opportunities in those districts where the Socialist Left or the Liberals had nominated women. First, however, let us turn to macrocontagion in Canada.

\section{Representation of Women in Canada}

The Canadian story of women's representation is not as well known, perhaps because until the parliamentary election of 1984 Canada was a laggard in this area. 
With a doubling of women's numbers in the House of Commons in 1984, from 5 to $10 \%$, however, and further increases to $13 \%$ in 1988 and to $18 \%$ in 1993 , Canada became a leader among single-member district countries. In comparison, despite noticeable increases after the 1992 elections, both the United Kingdom (9\%) and the United States $(11 \%)$ still are well behind Canada in proportion of female members of the most popularly elected house. There have been several hypotheses offered for the rise of women in Canada, including unexpected election results in 1984 vaulting presumed "sacrificial lambs" into office, pressure from feminist organizations, party nomination procedures, and high legislative turnover rates (Brodie 1985; Brodie and Chandler 1991; Erickson 1991; Young 1991; Bashevkin 1993; Studlar and Matland 1994).

As in Norway, all parties have made some moves toward enhancing access for women. The party most aggressively pushing for a greater share of political power for women has been the socialist party, the New Democrats. Since the 1970s the federal New Democrats, traditionally the third party in terms of votes and legislative seats in the Canadian federal House of Commons, have specifically organized to target electoral appeals at women (Gotell and Brodie 1991). In the 1980s the NDP adopted affirmative action methods in pursuit of its feminist agenda. For instance, in 1981 and 1983 the federal NDP passed affirmative action resolutions aimed at gender parity within the ranks of the party organization and ran seminars specifically aimed at recruiting and training women candidates (Gotell and Brodie 1991; Erickson 1993). The two other parties have followed the NDP, albeit less vigorously, in advocating a more participatory role for women in partisan politics.

Erickson (1993) notes, the NDP has tended to be first, most interventionist, and most centralized in programs to improve women's status within the party. The Liberals have tended to follow, be less interventionist, and rely more on local party cooperation, while the Conservatives have been the most reluctant to advocate special initiatives for women, most voluntaristic in implementation, and most reliant on local branches of the party. The New Democrats became the first significant party in Canada to have a federal-level woman party leader when Audrey McLaughlin was chosen in 1989. Although all parties now have larger numbers of women holding party positions, the New Democrats continue to lead (Bashevkin 1993).

On the provincial level, the New Democrats have been the leader in placing large numbers of women into legislatures and cabinets, especially in elections in 1990 and 1991 in Ontario, Saskatchewan, and British Columbia (Studlar and Matland 1996; Studlar and Moncrief 1995). While eschewing quotas, the other parties have encouraged greater participation by women in their ranks, including provincial legislatures and cabinets. All-male cabinets no longer exist in Canada. Two women have served as provincial premiers, and several others have been provincial party leaders.

In federal elections, the New Democrats have nominated the most women candidates, providing almost one half of the female candidates for the three traditional 
parties over the six federal elections between 1974 and 1993. Nevertheless, their third-place finishes overall have prevented them from putting many of these candidates into parliament. Thus the two larger parties, the Liberals and the Progressive Conservatives, have provided the bulk of women M.P.s. With a volatile electorate in Canada (LeDuc 1984; Clarke et al. 1991), however, the New Democrats' strong espousal of women's causes seems to have stimulated the other parties to respond (Gotell and Brodie 1991). Both of the larger parties began to profess a concern in increasing women candidacies as the issue became more prominent. For instance, before the election of 1984 the New Democrats and the Liberals created special funds to aid in the election of their women candidates; the Progressive Conservatives followed soon after the election (Erickson 1993).

Canada in 1991, then under a single-party Progressive Conservative government, had 18\% women in its Cabinet (Koole and Mair 1992), including the only female foreign minister in the industrialized world. In 1993 Kim Campbell, formerly Defense Minister and Justice Minister in Brian Mulroney's cabinets, succeeded the retiring Conservative Prime Minister. Thus, two of the three major party leaders in the federal election of 1993 were women. At their party conference in 1991, the New Democrats announced a goal of having 50\% female candidates for Parliament in the next federal election, a very ambitious goal for a party in a single-member district system with decentralized candidate selection processes. In fact, $38 \%$ of the NDP candidates in 1993 were women. Liberal Party leader Jean Chretien invoked his extraordinary power to approve federal parliamentary candidates primarily to increase the number of Liberal women in winnable seats in 1993. The Liberal goal was $25 \%$ women candidates; they finished at $21 \%$. The Conservative party slate included women as $22 \%$ of their federal candidates. Although the rising new parties, the Bloc Quebecois and the Reform Party, nominated fewer women ( $13 \%$ and $11 \%$, respectively), Canada still had a historically high $18 \%$ women in the House of Commons after the election. Events in Canada suggest that in a volatile party system, the New Democrats acted as a force for macrocontagion among other parties, both old and new.

Thus we have two polities with contrasting electoral systems, but both with multiparty systems and with similarly strong trends in advancing women to legislative and executive positions. In both systems, it appears that a process of macrocontagion has occurred by which parties, starting with those on the Left, have increasingly forwarded women candidates. While the idea of a general trend toward nominating more women via a macrocontagion process has face validity, contagion theory will be considerably strengthened if we can also find microcontagion occurring. It is to that task we now turn.

\section{Testing Microcontagion}

Microcontagion occurs when a party responds to the nomination of women candidates by another party by nominating its own women candidates in viable 
positions in the same constituencies. We expect a major party which competes directly with a minor party that is promoting women, to be most acutely pressured to respond. Since the parties promoting women candidates and issues are on the left side of the political spectrum in the two cases we are looking at, we theorize that contagion should affect the Labour party in Norway, i.e., the major party closest to the Socialist Left and Liberals, and the Liberal party in Canada, i.e., the major party closest to the NDP. ${ }^{6}$

Our expectations are that microcontagion does not work the same in these two countries. We would expect microcontagion to be more evident in Norway than in Canada. This is true because the party list system and greater district magnitude found in Norway makes it easier for the Norwegian Labour party to respond to contagion pressure. A party list system with a high district magnitude, as Norway has, allows a party to adjust by adding a woman (or women) to the list without having to pay the high cost of confronting other central party interests. In a singlemember district system the party may have to remove a sitting M.P. or shut out strong intraparty interests in order to run a woman. We believe that this cost will prove too high and that microcontagion effects will not be found in Canada.

Before asserting that not finding microcontagion is a foregone conclusion in Canada, let us point out several reasons why microcontagion is more likely to be found in Canada than in other single-member district systems. First, singlemember district systems are likely to have fewer parties and therefore less likely to have a party actively promoting women's rights. In choosing Canada, a country with more than two parties and one strongly promoting women, we pass these barriers. Second, the viability of the threat is often an important stumbling block for contagion in single-member district systems. If a party's position is so strong in a district that they face no serious electoral challenge, then they may simply ignore the innovating party's actions and no contagion will occur. Again, Canada is an outlier on the side favorable to contagion. First, while the NDP was clearly a third party, it was well established. The NDP garnered close to $20 \%$ of the vote in the three federal elections held in the 1980s and was considered an important actor by the other parties. Second, the Canadian electorate has proven to be extremely volatile. Massive movements have often occurred from one election to the next. This effectively means that in Canada no seat can be considered entirely safe. The two major parties cannot ignore third party challenges. ${ }^{\text {? }}$

\footnotetext{
${ }^{6}$ It is clear that Labour, the Socialist Left, and the Liberals compete for the same voters. Valen and Aardal (1983), using a panel study, found that among those voters who voted for the Socialist Left in 1977 , but for someone else in 1981, 75\% went to Labour. Among those who switched away from Labour, $45 \%$ went either to the Socialist Left or the Liberals.

${ }^{7}$ The 1993 election proved this point in a stunning manner. The Bloc Quebecois and the Reform Parties, who together held ten seats in the outgoing parliament, went on to win over 100 seats between them and completely decimated the Conservative party which fell from a majority of the seats in the 295 member House of Commons to only 2 seats.
} 
Testing Microcontagion in Canada. In the Canadian case the major party most affected by the minor party (NDP) promotion of women should be the Liberals. The microcontagion hypothesis is that the Liberal party will nominate more women in ridings (in Canada, a constituency is called a riding) where the NDP has nominated a woman, than in ridings where the NDP has nominated a man. The dependent variable is the same for both countries: the proportion of the district delegation that is female for the major party closest to the minor party promoting women. In Canada all districts are single-member districts, so the dependent variable measures whether the Liberal party candidate is a woman. If the candidate is a man the dependent variable is 0 ; if the candidate is a woman the dependent variable is 1 . Probit analysis is the obvious methodological tool to use. Probit analyses were run for the 1980, 1984, and 1988 elections. This period was chosen because it was the period in which a substantial increase in women's representation occurred. The number of cases in our initial analysis is equal to the number of constituencies. There were 282 ridings in 1980 and 1984 and 295 ridings in 1988.

The crucial independent variable, measuring contagion, is whether the NDP nominee in the district is a man or a woman. This variable is coded 1 if the nominee is a woman, 0 if a man. In addition to our primary variable of interest, the probits include a set of independent variables to control for district characteristics. Moncrief and Thompson (1991) found that urban districts in Canada tend to nominate more women than rural districts. Other work has refined this and identified women's labor force participation rates and levels of education in a district as important factors that affect female representation in Canada (Studlar and Matland 1994). In addition, whether the candidate is an incumbent has been shown to have a significant negative effect on the probability a candidate will be a woman.

The Canadian results are presented in table 2. We ran two different models. Model one tests for contagion in the same year, model two tests for contagion from the previous election. The second model, that contagion occurs from the previous election, was tested due to concern that it might take the Liberal party one election cycle before being able to react to the NDP's nomination of a woman. General party meetings held in each riding nominate the candidates. If the Liberals held their nomination meetings prior to the NDP's, they might not be able to react to the NDP's nomination of a woman in the same election. While this is of some concern, it is also true that even if the Liberals held their riding nomination meetings before the NDP's, often they would know whom the NDP expected to nominate in a riding and whether that person was a woman. Nevertheless, to give microcontagion another opportunity to appear we tested Model Two.

The control variables generally have the expected sign, and in all cases where they are significant they work in the manner predicted by theory. The independent variable testing for microcontagion shows no indication that contagion has had an affect on the Liberal party's propensity to nominate women. The effect is nonsignificant for all six probits and the sign is in the predicted direction for only two 
TABLE 2

Probit Results for Canada 1980, 1984, and 1988

\begin{tabular}{lcccccc}
\hline & Constant & $\begin{array}{c}\text { Incumbent } \\
\text { Candidate }\end{array}$ & $\begin{array}{c}\text { \% of Pop. } \\
\text { w/ Univ. } \\
\text { Education }\end{array}$ & $\begin{array}{c}\text { Women's } \\
\text { Labor Force } \\
\text { Part. Rate }\end{array}$ & $\begin{array}{c}\text { Contagion } \\
\text { from Same } \\
\text { Year }\end{array}$ & $\begin{array}{c}\text { Contagion } \\
\text { from Past } \\
\text { Election }\end{array}$ \\
\hline 1980 & & & & & & \\
Model 1 & $-2.64^{* *}$ & -.39 & -.03 & $.04^{*}$ & -.52 & $\mathrm{X}$ \\
Model 2 & $(.91)$ & $(.26)$ & $(.02)$ & $(.02)$ & $(.46)$ & \\
& $-2.64^{* *}$ & -.36 & -.03 & $.04 *$ & & -.29 \\
1984 & $(.90)$ & $(.26)$ & $(.02)$ & $(.02)$ & $\mathrm{X}$ & $(.36)$ \\
Model 1 & -.35 & $-.81^{* *}$ & .00 & -.01 & .28 & $\mathrm{X}$ \\
Model 2 & $(.77)$ & $(.23)$ & $(.02)$ & $(.02)$ & $(.22)$ & \\
& -.29 & $-.82^{* *}$ & .01 & -.01 & & -.00 \\
1988 & $(.76)$ & $(.23)$ & $(.02)$ & $(.02)$ & $\mathrm{X}$ & $(.30)$ \\
Model 1 & -1.41 & -.38 & $.03 *$ & .00 & -.01 & $\mathrm{X}$ \\
& $(.79)$ & $(.35)$ & $(.01)$ & $(.02)$ & $(.19)$ & \\
Model 2 & -1.36 & -.14 & $.04^{* *}$ & -.00 & & .10 \\
& $(1.00)$ & $(.39)$ & $(.01)$ & $(.02)$ & $\mathrm{X}$ & $(.24)$ \\
\hline
\end{tabular}

Dependent Variable $=$ Gender of Liberal Party Candidate $($ Woman $=1)$

* Significant at the .05 level, one-tailed test.

** Significant at the .01 level, one-tailed test.

$N=282$ for 1980 and 1984 .

$N=295$ for 1988 .

of the six probits. These data are consistent with our prediction and do not show any microcontagion effect occurring in Canada. ${ }^{8}$

While the initial results show little indication of any microcontagion effect across the country, the regional nature of party competition in Canada might mean that a true contagion effect could be masked by a set of districts where the Liberals

${ }^{8}$ While we argue that contagion should occur to the party closest to the innovator, it is possible that the innovation might be picked up by other parties. We tested the two models presented in table 2 using the gender of the Progressive Conservative party nominee as the dependent variable. When testing model 1 we found that for all three elections, the effect of the NDP nominating a woman on the probability that the PC nominated a woman was non-significant, and in two of the three cases the effect had the wrong sign, i.e., negative. Testing model 2, that the effect of contagion is lagged, produced some surprising results. The effect was nonsignificant in 1980, it was statistically significant and positive in 1984 (as predicted by the theory), and finally it was statistically significant and negative in 1988. While the 1984 results provides one straw of evidence in favor of contagion, the validity of that effect must be seriously questioned when the opposite effect appears in the very next election along with all the nonsignificant results reported for the other tests. In addition, further analysis shows that this result is largely driven by a strong correlation in Quebec ridings, between female NDP nominees in 1980, and 
and NDP were not effective competitors. Therefore we redid the analyses with only ridings where both the NDP and the Liberal party had at least $20 \%$ of the vote. The NDP or the Liberals won the majority of the ridings included in the second test. In those cases where the PC did win, it is reasonable to assume that the significant vote total for the third place finisher (i.e., either Liberal or NDP) is one reason that the PC won the seat. In other words, all these districts are districts where the Liberals and NDP are competitive.

There were 94 districts (33.3\% of all districts) which met or exceed this $20 / 20$ standard in 1980; 64 districts (22.7\% of all districts) were above the standard in 1984 ; and 89 (30.2\% of all districts) met it in $1988 .{ }^{9}$ We retested both contagion models for this subset of ridings for the three elections. Again there were no signs of microcontagion occurring. The microcontagion variable was insignificant in all six tests, and in only one case was the $t$-statistic above 1.00 .

Testing Microcontagion in Norway. In applying microcontagion to Norway, we concentrate on the Labour party. Labour has been the largest and most powerful political party in Norway throughout the post World War II period. Being on the left side of the political spectrum, Labour is the major party most likely to be sensitive to pro-women movements by the Socialist Left and the increasingly green Liberals. The expectation is that after the Socialist Left and the Liberal party began aggressively promoting women, the Labour party would start to feel pressured to do likewise. We expect this pressure to be most acute for local Labour party caucuses in those districts where the Socialist Left and/or the Liberals have nominated women prominently on their party lists.

For microcontagion to occur there must be a party (or parties) explicitly identified as promoting the issue of women's representation. This effectively precludes consideration of the elections before 1973, since the earliest campaigns for improved representation were across all parties. Continued discussion of the EEC referendum of the previous year completely dominated the 1973 elections. While there was pressure for increased representation, no party made the issue a centerpiece of their campaign. This changed radically, however, by 1977 when both the Socialist Left and the Liberals prominently featured their commitment to gender equality. Both parties established quotas for women candidates, and the female proportion of their party lists jumped dramatically from $26.2 \%$ in 1973 to $43.8 \%$ in 1977. Importantly, both parties were electoral threats to the Labour party. We therefore expect to see microcontagion play a role in 1977 and in the following election in 1981. In 1983, the Labour party instituted gender quotas. This party rule

\footnotetext{
female PC nominees in 1984. The NDP is extremely weak in Quebec, and until the 1984 elections so were the PC. It seems unlikely that the PC saw the NDP as an important threat to their electoral success in Quebec and therefore nominated more women to lure voters away from the NDP.

${ }^{9}$ More than $50 \%$ of these districts were in Ontario, with British Columbia being the next most common province. The rest of the ridings are largely in urban areas in the other provinces. Note the 1984 number is substantially lower than 1980 or 1988 , because of the PC landslide in that year.
} 
led to Labour quickly adopting a system of (near) equality across the country. By this time, macrocontagion had succeeded in getting the Labour party to alter its institutions, and we would not expect to see any effect of microcontagion in 1985 or 1989. This leaves us with a window of two elections, 1977 and 1981, in which to test for microcontagion.

There are 19 electoral districts in Norway, one for each county. Each electoral district elects several members of parliament, ranging from 4 to 15 . In the Canadian case the dependent variable was simply whether the Liberal party candidate was a woman; more formally it was the proportion of the party district delegation that was female. Developing a Norwegian equivalent to this is possible, but requires some explanation. The total number of names on a parliamentary list far exceeds the number of seats in the district, as the party lists also include alternates. In the city of Oslo, for example, there are 15 MPs. The Labour party won seven of these seats in 1977. The Labour party list for Oslo, however, had 21 names! Clearly most of those people knew they had no chance of serving in the parliament. There were just as many names on the lists for the other parties even though many had no hope of representation or could only hope to get one representative.

Under these conditions a party could profess to have equal representation, but place men in all the top of the list positions and place women in the bottom of the list positions. The list might be close to $50 \%$ women, but only men might be in positions that had a viable chance of getting elected. Therefore, it is important to distinguish between three different list positions: mandate, fighting, and ornamental (Haavio-Mannila et al. 1985). Mandate positions are those that the party is guaranteed to win; they are positions that the party has consistently held and short of a catastrophic election result will maintain. Since voters cannot alter the ordering of candidates on the party list, a person nominated for a mandate spot is as good as in the parliament immediately after the party nominating meetings. Fighting positions are those positions where the outcome is uncertain, but where the party has a chance to win the seat. These include seats a party has held, but might lose if they have a poor electoral campaign, or seats that the party has not held, but might win if they run a strong campaign. Finally, ornamental positions are exactly that; they are people who have no chance of being elected, but by placing them on the list the party hopes to attract supporters from the various causes its list members represent. Skard and Haavio-Mannila (1985) found that during the 1970s women were disproportionately represented among those ornamental positions that had no chance of getting elected. To avoid the danger of counting women who are in ornamental positions, the dependent variable developed is the female proportion of the nominees for winnable seats, i.e., those seats that were either mandate or fighting positions for the party. ${ }^{10}$

\footnotetext{
${ }^{10} \mathrm{We}$ analyzed each county's voting results to determine which list positions were mandate, fighting, or ornamental. Mandate seats were determined by subtracting $10 \%$ of the Labour party's vote or $3.5 \%$ of the total votes for the district, whichever was larger, from Labour's vote. We held the other parties' votes constant and then calculated how many seats Labour would have retained under these hypothetical results (seats in Norway are allocated using the St. Lague method of allocation). The individual
} 
While the dependent variable in the Canadian case is dichotomous, the dependent variable in the Norwegian case shows a wide dispersion from zero to $50 \%$ of the nominees for winnable seats being female. Therefore, we use standard OLS regression.

For symmetry with the Canadian case, we use county-level women's labour force participation rates and the percent of the county population having had gymnas (secondary school-second level) or more education (university). As in the Canadian case these variables are strongly correlated with urbanization and as such provide a control for urbanization. In the Canadian case, candidate incumbency negatively affects the probability that a woman will get nominated because there are no available seats. In the Norwegian case the same logic applies, but because a party may win several seats, the important thing is not whether a candidate is an incumbent, or how many of the party's candidates are incumbents, but rather how many winnable seats are open for new party candidates. We estimated this open seat variable by taking the number of winnable seats, i.e., the mandate plus the fighting seats, and subtracting the number of incumbents running. This provides an estimate of how many open seats are available where there is a realistic chance of the party's new candidates being elected to the parliament. This open seat variable also provides a control for party magnitude, the number of seats a party expects to win in a district. Earlier work on Norway (Matland 1993) shows that the proportion of a party's county delegation that is female is directly related to the size of the delegation. Not surprisingly there is a strong relationship between the number of open seats available and the total number of seats held by the party. ${ }^{11}$

The contagion variable measures whether the Liberals or the Socialist Left had nominated a woman in a prominent position on their lists. A prominent position is defined as either being a party's number one candidate or being nominated for a winnable seat. It is 0 if neither party nominated a woman for such a position, 1 if either party nominated a woman for such a position, and 2 if both parties nominated a woman for such a position. The number one candidate has a crucial position as the point person for the party within the district. Even when the party does not have a good chance of winning a seat, the number one candidate receives substantial mass media attention and is quite visible. In those districts where the Liberals

district votes are published in the official election statistics handbook (Norwegian Central Bureau of Statistics 1978,1982). Seats that the party was still certain of winning were mandate seats. All seats which a party had won, but would have lost had the poorer results actually occurred, became fighting seats. Seats the party had won at the previous election, but lost in this election, were also fighting seats. The second analysis was to test if improved results might have enabled Labour to garner seats above and beyond what they had actually won. To Labour's initial vote total we added $10 \%$ of Labour's vote or $3.5 \%$ of the entire district's vote, whichever was larger. The other party's votes were held constant. Then the new hypothetical results were evaluated to see if Labour would have been able to win additional seats. Where this was true, the seat was identified as a fighting seat. All seats which Labour would not have won even with the hypothetical improvements in their vote total were identified as ornamental seats.

${ }^{11}$ For 1977 the correlation between party magnitude and number of open seats is .42 . For 1981 the correlation is .74. 
TABLE 3

REGRESSION RESULTS FOR NORWAY, 1977 AND 1981

\begin{tabular}{cccccc}
\hline Year & Constant & $\begin{array}{c}\text { Women's } \\
\text { Labor Force } \\
\text { Part. Rate }\end{array}$ & Education & $\begin{array}{c}\text { Open } \\
\text { Seats }\end{array}$ & $\begin{array}{c}\text { Soc. Left \& } \\
\text { Liberals Number of } \\
\text { Prominent Candidates }\end{array}$ \\
\hline 1977 & 3.39 & .79 & $-.98^{*}$ & $5.95^{* *}$ & $8.69^{*}$ \\
& $(4.10)$ & $(.83)$ & $(.50)$ & $(2.42)$ & $(4.49)$ \\
1981 & 79.46 & -.93 & -.13 & $7.67^{*}$ & -5.12 \\
& $(49.54)$ & $(1.04)$ & $(.68)$ & $(3.91)$ & $(5.92)$ \\
\hline
\end{tabular}

Dependent Variable $=$ Female Proportion of Labor Party Candidates for Winnable Seats

1977: $N=19$.

$R$-squared $=.55$

Adjusted $R$-squared $=.43$

Standard Error $=.105$
1981: $N=19$

$R$-squared $=.31$

Adjusted $R$-squared $=.12$

Standard Error $=.135$

* Significant at the .05 level, one-tailed test.

** Significant at the .01 level, one-tailed test.

or the Socialist Left nominated a woman as the number one candidate, or for a winnable seat, it would create substantial pressure on the Labour party to nominate women in winnable positions. Since each party uses a nominating commission that announces its proposal for the party lists well before party nominating meetings are held, it is highly likely that the Labour party would know of the Liberals and Socialist Left's intention to nominate a woman in a prominent position before they finalized their party list. The test of contagion theory is whether the prominent candidate variable has a positive and statistically significant effect on the proportion of winnable seats occupied by Labour women.

Table 3 presents the regression results for 1977 and 1981. The control variables generally show the expected results. The open seat variable has a very strong and powerful effect in both years. This should hardly be surprising, as incumbency has been shown to be an impediment to increased female representation in many countries (Darcy, Welch, and Clark 1994). This variable shows that as the number of available seats increases, the proportion of women among the viable nominees also increases dramatically. Women's labor force participation had, as expected, a positive effect on women's proportion of the Labour candidates for winnable seats in 1977, but was negative in 1981; in neither year was the effect significant. Surprisingly, education has a negative effect in both years, and a statistically significant one in 1977. We are uncertain why this effect appears.

Contagion has the predicted effect in 1977. Labour party lists have proportionately more women nominated in winnable positions in those districts where the Liberals or the Socialist Left nominated a woman in prominent positions. The effect is also substantively significant, with Labour tending to nominate $8.7 \%$ more women in districts where one of the two innovators nominated a woman in a prominent position and fully $17.4 \%$ more in those constituencies where both the 
Socialist Left and the Liberals nominated women. ${ }^{12}$ This is exactly what microcontagion would predict and provides confirmation that microcontagion occurred in Norway during the 1977 elections. This effect cannot be explained as macrocontagion or an indication of changing social values. Those effects should be evident across all counties. What these results show is that it is exactly in those counties where the Socialist Left and the Liberals promoted women, that there was the highest proportion of women in winnable positions on Labour's lists.

The 1981 results, on the other hand, show that microcontagion no longer appears to be occurring. The effect of the Socialist Left and Liberals nominating women in prominent positions is negative, but nonsignificant. These results are surprising, as microcontagion had operated as predicted in 1977. Upon further inspection, however, we found that the 1981 results are very fragile. If one extreme case is removed, the effect changes from being negative to positive, albeit nonsignificant. ${ }^{13}$ In addition, careful inspection of the individual data points suggests that the Labour party was already well on its way to establishing gender quotas. Although they did not formally establish quotas until the 1983 national convention, it appears that already in 1981 Labour felt a need to increase their promotion of women, everywhere, regardless of whether the Socialist Left or Liberals had women running in prominent positions. The proportion of women in winnable positions on Labour party slates went up in nine counties, stayed the same in eight counties, and went down in only two counties. ${ }^{14}$ Comparisons of the 1981 lists with the 1977 lists show that in seven of the eight districts where more than one new name appears among the Labour candidates for mandate and fighting positions, a woman was added to the list. ${ }^{15}$ Of the 29 persons, in mandate or fighting positions, who were replaced on the Labour party's lists from 1977 to 1981, only five of them $(17 \%)$ were women. Of the 29 who were new in either mandate or fighting positions for the Labour party, fully 14 (48\%) of them were women. Although microcontagion effects do not show up in the 1981 regression, there are individual counties where microcontagion appears to occur. In Nordland, for example, where the Socialist Left elected a woman as their one representative in 1977, the three new names in mandate or fighting positions for the Labour party were all women (increasing women's proportion of mandate and fighting nominations in Nordland

\footnotetext{
${ }^{12}$ Considering that only $24 \%$ of the MPs elected in 1977 were women, these are quite marked effects.

${ }^{13}$ The one case is the county of Vest-Agder, where both the Liberals and Socialist Left nominated women, but where neither of the two Labour mandate or fighting positions were women.

${ }^{14}$ The only reason the proportion went down in two counties is a mathematical fluke caused by the Labour party doing substantially worse in those two counties than they had in the 1977 election. In both counties women were running for a position that was a fighting position in 1977, but an ornamental one in 1981. While women were 2 of 5 winnable positions in Akershus in 1977, they were 1 of 4 winnable positions in 1981. The women's proportion therefore decreased from $40 \%$ to $25 \%$. It is important to note, however, that a woman was in the fifth position on the Akershus list. If the Labour party had done as well in 1981 as they did in 1977 in Akershus and Rogaland, the proportion of women in winnable positions would have been the same and nowhere in the country would there have been a decrease in women's representation on Labour's lists.

${ }^{15}$ Vest-Agder is again the exception.
} 
from $14 \%$ to $50 \%$ ). What we find when we look at the raw data is that Labour women were making significant advances in representation in virtually every county, not just in those districts where the Socialist Left and Liberals had prominent candidates. Microcontagion does not have a statistically significant effect in 1981 , because Labour was already feeling strong macrocontagion pressure, and was reacting to that pressure in all counties.

\section{ConCLUSION}

At the outset we noted that there exists a growing gap between single member and multimember district systems in the female proportion of legislatures. After reviewing the literature, we proposed contagion theory as a possible explanation for the existing differences. After distinguishing between macro- and microcontagion, we turned to testing for these types of contagion in two countries. While evidence for macrocontagion could be found in both countries, we found sharp differences in the existence of microcontagion. In choosing Canada as the representative for single-member district systems, we purposely chose a country where the probability of finding microcontagion was strong. Yet the Canadian data show no indication of any microcontagion process.

The Norwegian case, on the other hand, provided support for the argument that innovative policies established by fringe parties can affect the traditional parties, not only generally, but in specific contests. Within the Norwegian context this is especially important as it establishes the effect of the Liberal and Socialist Left quota policies on female representation. The direct effect of the Liberals and the Socialist Left establishing quotas was virtually zero. In the 1977 elections these two parties only elected four representatives, one of whom was a woman. In 1981 their total representation increased from four to six, only two were women. The indirect effect of pressuring Labour, however, was substantially larger. From 1973 to 1977 the number of women in Labour's parliamentary delegation increased from 12 to 20 and this total again increased in 1981 to 22, despite Labour losing 10 seats in the 1981 election.

At a theoretical level, microcontagion theory provides a reasonable and now empirically supported, explanation for why we find consistent differences across electoral systems in the level of female representation. It provides an explanation for why there has been a consistent gap between single-member district and party list proportional representation systems, and why representation has increased much more swiftly in proportional representation systems.

While the emphasis here has not been on party change per se, we believe some tentative claims about party change can be made based on these results. First, the environment strongly influences parties (Harmel and Janda 1982). More specifically, the electoral system structure distinctively influences party behavior. Second, parties are conservative organizations that are not easily moved to change their policies. In the Canadian case where, because of the single-member district election structure, there was a high cost of responding to pressures for equal represen- 
tation, there was no evidence of a microcontagion effect. Third, parties can adapt when either the costs of change are limited or the apparent payoffs are clear. In party list proportional representation systems, such as Norway, there are lower costs of changing, and the expected payoffs are more certain. Under these conditions we do find parties adapting and the predicted microcontagion effects appear. The differences in the two countries are very much tied to the electoral systems. Because of this crucial difference, it is likely that party list proportional representation systems will show more rapid increases in representation of women than single-member district systems. The Norwegian case also seems to suggest that there is some interaction, with effective microcontagion having the effect of speeding along macrocontagion effects.

These results provide a plausible explanation for variations in representation. Nevertheless, the contagion hypothesis is far from completely developed or, for that matter, conclusively demonstrated. While the Canadian results were as predicted and the Norwegian results largely as expected (with a plausible explanation for the one important nonfinding), these results represent only two countries. Contagion needs testing in additional countries and at different levels. This article has emphasized the possibility of microcontagion explaining differences between single-member district and proportional representation systems. It may also be true that contagion can help explain differences in representation levels across countries that all have proportional representation systems. Contagion theory is a process theory that describes how actions can develop (Mohr 1983). The developments described by the theory, however, are not guaranteed to occur. If no party actively promotes women's representation, there would be no innovation to be diffused across the other parties. It might be that those countries with proportional representation systems that are leaders in female representation have experienced contagion while those countries with PR systems which lag behind are those where no contagion has occurred.

Further research should look at what institutional and environmental factors are conducive to both macro- and microcontagion. One important factor that will fluctuate and may affect contagion's effectiveness is the strength and level of resources of women's groups within the major party being influenced by the fringe party. Contagion from fringe to mainstream parties is more likely to be successful on the Left. This is because major parties on the Left may feel a need to be sensitive to groups traditionally excluded from the circles of power, but also because these parties often have strong internal women's movements that can seize the opportunity and use the fringe party's promotion of women to promote their policy aims within their party. The more powerful these internal women's groups initially are, the more likely contagion will succeed. Certainly in the Norwegian case, the strength of the women's movement within the Labour party is an important part of the explanation for why contagion occurred so quickly in Norway.

Another factor that needs to be investigated is whether microcontagion depends more on party magnitude, i.e., the number of seats the party expects to win, or on the nominating system. It seems likely in proportional representation systems with 
low district magnitudes, for example Ireland or Iceland, that a party trying to decide how to react to the promotion of greater female representation from a competitor, might face a dilemma similar to the one faced by parties in single-member districts. The internal party dynamics may be such that if the party responds to the challenge by nominating more women, it must necessarily shut out traditional party interests that are used to having access. Under these conditions it seems at least plausible that microcontagion's effect would be attenuated even in a proportional representation system.

Manuscript submitted 27 January 1995

Final manuscript received 20 October 1995

\section{REFERENCES}

Aitken, Judith. 1980. "Women in New Zealand Politics." In New Zealand at The Polls, ed. Howard R. Penniman. Washington: American Enterprise Institute.

Andersen, Kristi, and Stuart Thorson. 1984. "Congressional Turnover and the Election of Women." Western Political Quarterly 37:143-56.

Bashevkin, Sylvia. 1991. "Women's Participation in Political Parties." In Women in Canadian Politics: Toward Equity in Representation, ed. Kathy Megyery. Vol. 6 of the Research Studies of the Royal Commission on Electoral Reform and Party Financing. Toronto: Dundern Press.

Bashevkin, Sylvia. 1993. Toeing The Lines: Women and Party Politics in English Canada. 2d ed. Toronto: University of Toronto Press.

$\rightarrow$ Bashevkin, Sylvia. 1994. "Confronting Neo-Conservatism: Anglo-American Women's Movements under Thatcher, Reagan, and Mulroney." International Political Science Research 15:275-96.

Beckwith, Karen. 1990. "Candidature Femminili E Sistemi Elettorali." [Women Candidates and the Electoral System]. Revista Italiana di Scienza 20:73-103.

Bochel, John, and David Denver. 1983. "Candidate Selection in the Labour Party: What the Selectors Seek." British Fournal of Political Science 13:45-69.

Brodie, Janine. 1985. Women and Politics in Canada. Toronto: McGraw-Hill Ryerson.

Brodie, Janine, and Celia Chandler. 1991. "Women and the Electoral Process in Canada." In Women in Canadian Politics: Toward Equity in Representation, ed. Kathy Megyery. Volume 6 of the Royal Commission on Electoral Reform and Party Financing. Toronto: Dundern Press.

Bystydzienski, Jill. 1988. "Women in Politics in Norway." Women and Politics 8:73-95.

Bystydzienski, Jill. 1994. "Norway: Achieving World-Record Women's Representation in Government". In Electoral Systems in Comparative Perspective: Their Impact on Women and Minorities, ed. Wilma Rule and Joseph Zimmerman. New York: Greenwood Press.

Castles, Francis. 1981. "Female Legislative Representation and the Electoral System." Politics 1: $21-26$.

Chamberlin, John. 1990. "Formal Political Theory and the Design and Evaluation of Institutions." In Institutions in American Society: Essays in Market, Political, and Social Organizations, ed. John E. Jackson. Ann Arbor, MI: University of Michigan Press.

Christiansen, Thomas. 1976. "Kvinner som Politisk Trekkplaster." [Women as Political Bandaids.] Tidskrift for Samfunnsforskning 17:135-57.

Clarke, Harold D., Jane Jenson, Lawrence LeDuc, and Jon H. Pammett. 1991. Absent Mandate: Interpreting Change in Canadian Elections. $2 \mathrm{~d}$ ed. Toronto: Gage.

Darcy, R., and James R. Choike. 1986. "A Formal Analysis of Legislative Turnover: Women Candidates and Legislative Turnover." American Fournal of Political Science 30:237-55. 
Darcy, R., and Sarah Slavin Schramm. 1977. "When Women Run Against Men." Public Opinion Quarterly 41:1-12.

Darcy, R., Susan Welch, and Janet Clark. 1994. Women, Elections and Representation. 2d ed. Lincoln: University of Nebraska Press.

Duverger, Maurice. 1954. Political Parties: Their Organization and Activity in the Modern State. London: Methuen.

Duverger, Maurice. 1955. The Political Role of Women. Paris: UNESCO.

Engstrom, Richard. 1987. "District Magnitude and the Election of Women to the Irish Dail." Electoral Studies 6: 123-32.

Epstein, Leon. 1967. Political Parties in Western Democracies. New York: Praeger.

Erickson, Lynda. 1991. "Women and Candidacies for the House of Commons." In Women in Canadian Politics: Toward Equity in Representation, ed. Kathy Megyery. Vol. 6 of Research Studies of the Royal Commission on Electoral Reform and Party Financing. Toronto: Dundern Press.

Erickson, Lynda. 1993. "Making Her Way In: Women, Parties, and Candidacies in Canada." In Gender and Party Politics, ed. Joni Lovenduski and Pippa Norris. London: Sage.

Gallagher, Michael, and Michael Marsh. (eds.). 1988. Candidate Selection in Comparative Perspective: The Secret Garden of Politics. London: Sage.

Gelb, Joyce. 1989. Feminism and Politics. Berkeley: University of California Press.

Gotell, Lise, and Janine Brodie. 1991. "Women and Parties: More Than an Issue of Numbers." In Party Politics in Canada, 6th ed., ed. Hugh G. Thorburn. Scarborough: Prentice-Hall Canada.

Grepstad, Ottar, and Jostein Nerbøvik.1984. Venstres Hundre Aar. [The Liberal Party's 100 Years]. Oslo: Gyldendal.

Haavio-Mannila, Elina, Drude Dahlerup, Maud Eduards, Esther Gudmondsdottir, Beatrice Halsaa, Helga Hernes, Eva Hanninen-Salmelin, Bergthora Sigmundsdottir, Sirka Sinkkonen, and Torild Skard. 1985. Unfinished Democracy: Women in Nordic Politics. Trans. Christine Badcock. New York: Pergamon.

Hannan, Michael T., and John Freeman. 1977. "The Population Ecology of Organizations." American Fournal of Sociology 82:929-64.

Hannan, Michael T., and John Freeman. 1984. "Structural Inertia and Organizational Change." American Sociological Reviem 49:149-64.

Hannan, Michae! T., and John Freeman. 1989. Organizational Ecology. Cambridge, MA: Harvard University Press.

Harmel, Robert, and Kenneth Janda. 1982. Parties and Their Environments: Limits to Reforms? New York: Longman Press.

Harmel, Robert, and Kenneth Janda. 1994. "An Integrated Theory of Party Goals and Party Change." Fournal of Theoretical Politics 6 (3):259-88.

Hofferbert, Richard I., and Ian Budge. 1992. "The Party Mandate and the Westminister Model: Election Programmes and Government Spending in Britain, 1948-85." British Fournal of Political Science 22:151-82.

Hunter, Alfred A., and Margaret A. Denton. 1984. "Do Female Candidates Lose Votes? The Experience of Female Candidates in the 1979 and 1980 Canadian General Elections." Canadian Review of Sociology and Anthropology 21:395-406.

Inter Parliamentary Union. 1993. Distribution of Seats Between Men and Women in the 171 National Parliaments Existing as of fune 30, 1993. Geneva: IPU.

Katzenstein, Mary Fainsod, and Carol McClurg Mueller, eds. 1987. The Women's Movement of the United States and Western Europe. Philadelphia: Temple University Press.

Kelley, Jonathon, and Ian McAllister. 1984. "Ballot Paper Cues and the Vote in Australia and Britain: Alphabetic Voting, Sex and Title." Public Opinion Quarterly 48:452-66.

Kirchheimer, Otto. 1966. "The Transformation of Western European Party Systems." In Political Parties and Political Development, ed. Joseph LaPalombara and Myron Weiner. Princeton, NJ: Princeton University Press. 
Kolinsky, Eva. 1991. "Political Participation and Parliamentary Careers: Women's Quotas in West Germany." West European Politics 14:56-72.

Koole, Ruud, and Peter Mair. 1992. "Editor's Introduction." European fournal of Political Research 22:347-50.

Krouwel, Andre. 1994. "Changes in Party Organizations and Kirchheimer's Catch-All Thesis: The Partial Decline of Parties." Presented at the annual meeting of The European Consortium for Political Research, Madrid, Spain.

Lakeman, Enid. 1970. How Democracies Vote. London: Faber.

Lancaster, Thomas D., and Rebecca Davis. 1992. "European Electoral Structures and Women's Political Participation: A Comparative Study in the Federal Republic of Germany." Presented at annual meeting of the Midwest Political Science Association, Chicago.

LeDuc, Larry. 1984. "Canada: The Politics of Stable Dealignment." In Electoral Change in Advanced Industrial Democracies: Realignment or Dealignment?, ed. Russell J. Dalton, Scott C. Flanagan, and Paul Allen Beck. Princeton: Princeton University Press.

MacDonald, Stuart Elaine, Ola Listhaug, and George Rabinowitz. 1991. "Issues and Party Support in Multiparty Systems." American Political Science Reviem 85:1107-33.

March, James G., and Herbert A. Simon. 1958. Organizations. New York: Wiley.

Matland, Richard E. 1993. "Institutional Variables Affecting Female Representation in National Legislatures: The Case of Norway." fournal of Politics 55:737-55.

Matland, Richard E. 1994. "Putting Scandinavian Equality to the Test: An Experimental Evaluation of Gender Stereotyping of Political Candidates in a Sample of Norwegian Voters." British fournal of Political Science 24:66-85.

Matland, Richard E. 1995. "How the Election System Structure has helped Women Close the Representation Gap in Norway". In Closing the Gap: Women in Nordic Politics, ed. Lauri Karvonen and Per Selle. London: Dartmouth.

Matland, Richard E., and Donley T. Studlar. 1995. "The Determinants of Legislative Turnover: A Cross-National Study." Presented at the annual meeting of the American Political Science Association, Chicago.

Means, Ingunn Norderval. 1972. "Political Recruitment of Women in Norway." Western Political Quarterly 25:491-521.

Means, Ingunn Norderval. 1973. Kvinner i Norsk Politikk. [Women in Norwegian Politics.] Oslo, Norway: Cappelens Forlag.

Mohr, Lawrence B. 1982. Explaining Organizational Behavior. San Francisco: Jossey-Bass.

$\rightarrow$ Moncrief, Gary F., and Joel A. Thompson. 1991. "Urban and Rural Ridings and Women in Provincial Politics: A Research Note on Female MLAs." Canadian fournal of Political Science 24:831-37.

Norris, Pippa. 1985. "Women's Legislative Representation in Western Europe." West European Politics 8:90-101.

Norris, Pippa. 1987. Politics and Sexual Equality. Boulder, CO: Rienner.

Norris, Pippa. 1993. "Conclusions: Comparing Legislative Recruitment." In Gender and Party Politics, ed. Joni Lovenduski and Pippa Norris. London: Sage.

Norris, Pippa, R. K. Carty, Lynda Erickson, Joni Lovenduski, and Marian Simms. 1990. "Party Selectorates in Australia, Britain, and Canada: Prolegomena for Research in the 1990s." Fournal of Commonmealth and Comparative Politics 28:219-45.

Norris, Pippa, and Joni Lovenduski. 1993. "Gender and Party Politics in Britain." In Gender and Party Politics, ed. Joni Lovenduski and Pippa Norris. London: Sage.

Norris, Pippa, Elizabeth Vallance, and Joni Lovenduski. 1992. "Do Candidates Make a Difference? Gender, Race, Ideology and Incumbency." Parliamentary Affairs 45:496-517.

Norwegian Central Bureau of Statistics. 1978. Storting Elections, 1977. Oslo, Norway: Central Bureau of Statistics.

Norwegian Central Bureau of Statistics. 1982. Storting Elections, 1981. Oslo, Norway: Central Bureau of Statistics. 
Panebianco, Angelo. 1988. Political Parties: Organization and Power. Cambridge, England: Cambridge University Press.

$\rightarrow$ Petry, Francois. 1988. "The Policy Impact of Canadian Party Programs: Public Expenditure Growth and Contagion From the Left." Canadian Public Policy 14:376-89.

Rabinowitz, George, Stuart Elaine MacDonald, and Ola Listhaug. 1991. "New Players in an Old Game: Party Strategy in Multiparty Systems." Comparative Political Studies 24:147-85.

Randall, Vicky. 1987. Women and Politics: An International Perspective. 2d ed. Chicago: University of Chicago Press.

Ranney, Austin. 1965. Pathmays to Parliament. Madison: University of Wisconsin Press.

Rasmussen, Jorgen. 1981. "Female Career Patterns and Leadership Disabilities in Britain: The Crucial Role of Gatekeepers in Regulating Entry to the Political Elite." Polity 13: 600-20.

Rasmussen, Jorgen. 1983. "Women's Role in Contemporary British Politics: Impediments to Parliamentary Candidature." Parliamentary Affairs 36:300-15.

Rule, Wilma. 1981. "Why Women Don't Run: The Critical Contextual Factors in Women's Representation." Western Political Quarterly 34:60-77.

Rule, Wilma. 1987. "Electoral Systems, Contextual Factors and Women's Opportunity for Election to Parliament in Twenty-Three Democracies." Western Political Quarterly 40: 477-498.

Skard, Torild, and Elina Haavio-Mannila. 1985. "Women in Parliament." In Unfinished Democracy: Women in Nordic Politics, ed. E. Haavio-Mannila, et al. New York: Pergamon.

$\rightarrow$ Studlar, Donley T., and Richard E. Matland. 1994. "The Growth of Women's Representation in the Canadian House of Commons and the Election of 1984: A Reappraisal." Canadian Fournal of Political Science 27:53-79.

Studlar, Donley T., and Richard E. Matland. 1996. "The Dynamics of Women's Representation in the Canadian Provinces: 1975-1994." Canadian Fournal of Political Science 29. Forthcoming.

Studlar, Donley T., and Gary F. Moncrief, 1995. "The Recruitment of Women Cabinet Ministers in the Canadian Provinces." Presented at biennial meeting of the American Association of Canadian Studies in the United States, Seattle, WA.

Studlar, Donley T., and Susan Welch. 1992. "The Party System and the Representation of Women in English Metropolitan Boroughs." Electoral Studies 11:62-69.

Valen, Henry. 1966. "The Recruitment of Parliamentary Nominees in Norway." Scandinavian Political Studies 1:121-66.

Valen, Henry, and Bernt Aardal. 1983. Et Valg i Perspektiv: En Studie av Stortingsvalget 1981. [An Election in Perspective: A Study of the Parliamentary Election of 1981]. Oslo, Norway: Central Bureau of Statistics.

Vallance, Elizabeth. 1984. "Women Candidates in the 1983 General Election." Parliamentary Affairs $37: 301-109$.

Welch, Susan, and Donley T. Studlar. 1986. "British Public Opinion Toward Women in Politics: A Comparative Perspective." Western Political Quarterly 39:138-52.

Young, Lisa. 1991. "Legislative Turnover and the Election of Women to the Canadian House of Commons." In Women in Canadian Politics: Tomard Equity in Representation, ed. Kathy Megyery. Vol. 6 of the Research Studies of the Royal Commission on Electoral Reform and Party Financing. Toronto: Dundern Press.

Richard E. Matland is assistant professor of political science, University of Houston, Houston, TX 77024-3474.

Donley T. Studlar is professor of political science, West Virginia University, Morgantown, WV 26506-6317. 